\title{
Épületek napenergia-potenciáljának számítása fotogrammetriai módszerekkel elóállított adatok felhasználásával
}

\author{
VARGA Ákos - SZATMÁRIJózsef - TOBAK Zalán - Boudewijn van LEEUWEN - MUCSI László
}

DOI: $10.30921 / G K .73 .2021 .2 .1$

\begin{abstract}
Absztrakt: A tanulmányban fotogrammetriai módszerrel feldolgozott légi felvételekböl kinyert adatokat használtunk fel 3D-s épületmodellek létrehozására, és ezeken alapuló szolárenergiapotenciál-számításokat végeztünk két szegedi mintaterületen. A felvételek fotogrammetriai feldolgozását követően az objektumalapú képelemzés segítségével a tetôk fölé érố vegetációt különítettük el, majd RANSAC-algoritmuson alapuló síkdetektálást alkalmaztunk az egyes tetôsíkok pontfelhöből történô kinyerésére. Ezen lépések kimeneteit felhasználva kiszámítottuk a rájuk esố szolárenergiaértékeket. Procedurális modellezési eljárásokkal vizualizáltuk a végsó modelleket. A kapott eredmények alapján elmondható, hogy a mintaterületek épületeinek döntô többsége alkalmas napelemek telepítésére, és a bennük rejlö napenergia-potenciál mindenképpen említésre méltó mindkét vizsgált területen.
\end{abstract}

Abstract: The main goal of the study was to use the data obtained from aerial photographs processed by photogrammetric methods to create $3 D$ building models and to perform solar-energy potential calculations based on them. Examining two sample areas in Szeged, Hungary several methods were used during the data processing. After photogrammetric processing of the images, vegetation over the roofs was isolated using object-based image analysis (OBIA), then plane detection based on RANSAC-algorithm was used to extract each roofplane from the point cloud. Using the outputs of these steps, we calculated the solar energy values of the planes. The final models were visualized by using procedural modeling. Based on the obtained results, it can be stated that most of the buildings in the sample areas are suitable for the installation of solar panels, and their potential is definitely noteworthy in both areas.

Kulcsszavak: szolárenergia, fotogrammetria, objektum alapú képelemzés, RANSAC, síkdetektálás Keywords: solar energy, photogrammetry, object based image analysis, RANSAC, plane detection

\section{Bevezetés}

Az elmúlt évtizedekben az emberiségnek egyre komolyabb kihívásokkal és változásokkal kell szembenéznie, többek között olyan, egymásra kölcsönösen ható folyamatokkal, mint a klímaváltozás, a demográfiai változások, az urbanizáció, a globalizáció és a fogyasztás-orientált gazdaságok átalakulása energiahatékony és fenntartható gazdaságok felé. A városok 3D-s modellezése egyre nagyobb szerepet kap, egyre több területen válik kívánatossá, szükségessé a sokszínú felhasználási lehetôségeinek, az egyre növekvő információ-mennyiségnek és az ezzel járó folyamatos technológiai fejlôdésnek köszönhetốn. Napjaink egyik népszerú településfejlesztési irányzata az okosváros-koncepció mind a tudományos, mind a döntéshozói közegekben és a köztudatban is egyre népszerúbb (Szatmári et al. 2019). Mivel az emberiség számára egyre inkább nyilvánvalóvá válik, hogy a jövố kulcsa a fenntartható fejlődésben rejlik (Henits et al. 2017), világszerte számos ország és város ösztönzi a napenergia használatát az egyéb energiatechnológiák mellett.

A napenergia aktív és passzív felhasználása hatékonyabbá teheti az energiagazdálkodást a városi, kereskedelmi és ipari terekben egyaránt. Aktív múködése során a rendszerbe visszatermelt villamos energia egyaránt tehermentesítheti a szolgáltatókat és fogyasztókat, hatékonyabbá téve az elosztást a jogi és infrastrukturális környezet lehetôségein és korlátain belül (Gál-Mucsi 2015). Passzív alkalmazása során az épületek tetôire, homlokzatára rögzített panelek segíthetik az energia-háztartás optimalizálását a tervezéstôl kezdve a hosszú távú fenntartásig.

Az elmúlt évtizedek rohamos tempójú technológiai fejlôdésének köszönhetôen jelentős előrelépés történt a besugárzási modellek terén is analitikai, numerikus-szimulációs, statisztikai módszerek bevezetésévél és fejlesztésével (Kodysh et al. 2013). Ezen módszerek közös jellemzóje volt azonban, hogy nagy mennyiségú, többnyire empirikus úton beszerezhetố adatot igényeltek, melyek gyakran (pl. a nehezen elérhetố térszíneken) korlátozták a lehetôségeiket. A GIS megjelenése (Hofierka-Š́ri 2002; Hammer et al. 2003; Šúri-Hofierka 2004), hardveres és szoftveres fejlôdése a területen nagy elốrelépést jelentett, többek között a felszínmodellek könnyebb elérhetősége, egyre jobb minôsége egyaránt lehetôvé tette a korábbi akadályok áthidalását és új módszerek kidolgozását. Különös figyelmet érdemelnek a mesterséges intelligenciát, gépi tanulást alkalmazó módszerek (Mohandes et al. 1998; Tymvios et al. 2005; MubiruBanda 2008), hiszen ezek révén gyorsabbá és hatékonyabbá válik a napelemek telepítésével kapcsolatos térbeli problémák megoldása. Ugyan hazánkban is számos tanulmány született a témában, (Gál-Unger 2011, FrankMucsi 2014, Gál-Mucsi 2015, Szabó et al. 2016), a terület nem tartozik a gyakran kutatottak közé.

A kutatás célja egy olyan módszer fejlesztése, bemutatása, mely a 
rendelkezésre álló adatokban rejló lehetôségeket és korlátokat figyelembe véve lehetôvé teszi a valósághú tetôsíkokat tartalmazó 3D-s épületmodellek létrehozását, majd ezen eredmények további felhasználását az épületek, illetve az egyes tetőszegmensek napenergia-potenciáljának kiszámítása során.

A tanulmányban az alábbi kérdésekre keressük a választ:

- Az alkalmazott módszerek alkalmasak-e a feldolgozás és a vizsgálatok hatékony elvégzésére?

- A mintaterület épületei alkalmasak-e napelemek telepítésére?

- Az eredmények alapján az egyes tetôk mekkora napenergia-potenciállal rendelkeznek?

\section{Adat és módszer}

\subsection{A felhasznált légi}

\section{felvételek és feldolgozásuk}

A feldolgozás során használt felvételek a Szegedi Tudományegyetem Geoinformatikai, Természet- és Környezetföldrajzi Tanszékének, illetve a légi felvételezés platformjául szolgáló Cessna kisrepülőgépet üzemeltetố külsố partner munkatársainak együttmúködésével készültek. A felvételezés két mintaterületen, a szegedi Alsóvárosban, illetve az ÚjrókusMakkosháza-Északi-város városrészek által határolt Vértó környékén történt, kb. 600 méter felszín feletti magasságból, így elérve a kívánt $5 \mathrm{~cm}$-es terepi felbontást. A tanulmányban ismertetett pontfelhô az itt adott pontsưrúséggel légi lézeres eljárással is előállítható, amelynek gazdaságosságát nem vizsgáltuk. A rendelkezésre álló

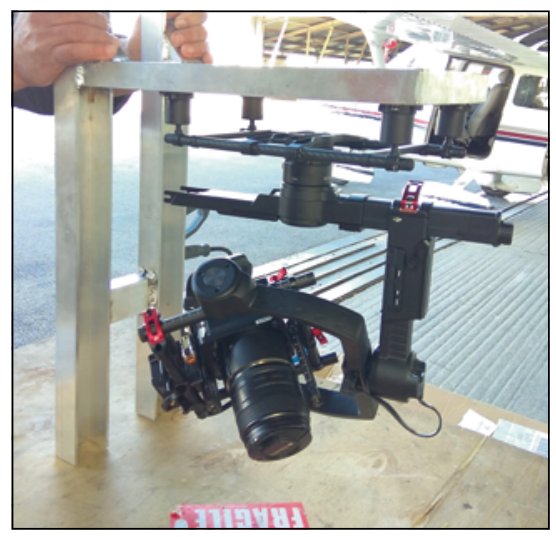

1. ábra. A felmérés során használt kamera és tartószerkezete a gimballal eszközeink az alapadatok fotogrammetriai úton történố elốállítását tették lehetôvé

A légi felvételeket az AgiSoft Metashape Professional fotogrammetriai szoftverrel dolgoztuk fel. Elsôdleges bemeneti adatok a légi fotók, a hozzájuk tartozó metaadat, illetve a georeferálás során használt, a tanszék munkatársai által korábban felmért földi illesztôpontok voltak. A további másodlagos inputadatok (ortofotó, felszínmodell, pontfelhő, épületpoligonok) mind a különbözố munkafolyamatok eredményeként jöttek létre a feldolgozás során.

Az adatgyújtéshez használt eszközök paraméterei (1. ábra):

- Repülőgép típusa: Cessna-172

- Gimbal típusa: DJI Ronin MX

- Kamera típusa: PhaseOne iXU150 középformátumú RGB $50 \mathrm{MP}$, $8280 \times 6208$ felbontás

- Objektív: Schneider Kreuznach, $55 \mathrm{~mm} \mathrm{f} / 2,8$

- Pixelméret: 5,3 $\mu \mathrm{m}$

A végső eredmények előállításához számos lépést, illetve módszert alkalmaztunk, melynek sarkalatos pontja a nyers légi fotók fotogrammetriai úton történố feldolgozása volt. Ez a munkafolyamat, illetve a megfelelően kiválasztott beállítások kulcsfontosságúak voltak a feldolgozás további részeit illetôen, mivel nagyban meghatározták az ortofotó, a pontfelhố és a felszínmodell, ezáltal minden ezekre épüló lépés kimenetének a minôségét is. A feldolgozás célja nagy térbeli felbontású és pontosságú termék előállítása volt. Az alsóvárosi mintaterületet $102 \mathrm{db}$, a Vértó mintaterületet pedig 246 db kép fedte le. Elôbbinél a georeferáláshoz $14 \mathrm{db}$, míg utóbbi esetében $6 \mathrm{db}$ RTK GNSS-múszerrel mért felszíni illesztôpontot (GCP-t) használtunk fel, így a légiháromszögelés eredményeként a tömbökre $3,83 \mathrm{~cm}$-es és 3,91 cm-es RMS-hibát kaptunk.

\subsection{Vegetáció eltávolítása objektumalapú képelemzéssel} A számítások pontosságának és a valósághú modellek létrehozásának érdekében szükséges volt a tetôk fölé belógó vegetáció kiszúrése, elkülönítése és a pontfelhô tisztítása, melyekhez az objektumalapú képelemzés módszerét (OBIA - Object Based Image Analysis) alkalmaztuk (Hossain-Chen 2019). A hagyományos, pixelalapú képvizsgálati módszerekkel összevetve, melyek leginkább a spektrális tulajdonságokon és textúrán alapulnak, ennek legfôbb jellemzôje, hogy az objektumok térbeli viszonyai, jellemzói (alak, méret, objektumon belüli pixelértékek, szomszédság stb.) kerülnek elötérbe (Hay-Castilla 2008). Egyik kritikus lépése a szegmentáció, melynek célja a keletkezố képobjektumok és a leképezett földfelszíni objektumok közötti kapcsolat megteremtése, illetve annak definiálása (Blaschke et al. 2008). Másik fontos lépése az objektumokon alapuló tulajdonságok kinyerése, illetve az osztályozás. A feldolgozás ezen részét Trimble eCognition szoftverrel végeztük el.

A folyamat során bemeneti adatként a légi felvételek feldolgozásából származó digitális felszínmodell, illetve az ortofotó szolgáltak. Az először elméleti, majd késôbb empirikus úton létrejött szabálykészlet (ruleset) meghatározó elemei az objektumokat eredményezô szegmentálás (chessboard, multiresolution), a különbözô szomszédsági (relative to) és az egyes objektumok pixelértékein (brightness, greenness stb.) alapuló eljárások, végül az osztályozás (assign class) voltak. A módszert csak az alsóvárosi mintaterületen alkalmaztuk, annak családi házas, „zöldebb” jellege miatt, míg a Vértó mintaterületen található panel-és társasházak magasságából fakadóan nem volt zavaró a vegetáció jelenléte. Ezen

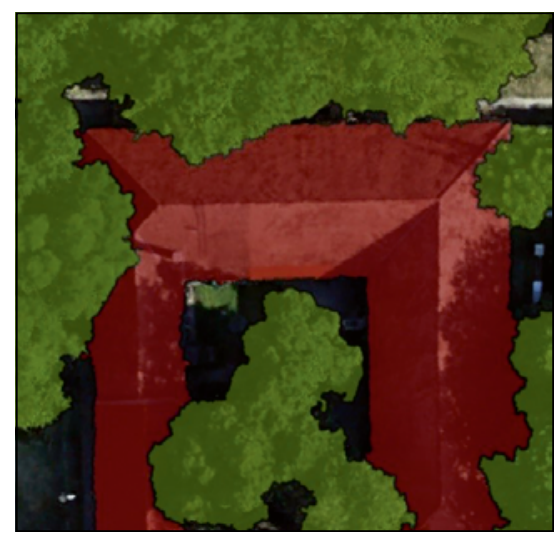

2. ábra. Az OBIA után kapott vegetációs maszk részlete 
lépés eredménye egy shape-állomány lett, amely a továbbiakban lehetôvé tette a vegetáció többi tereptárgytól történô elkülönítését (2. ábra).

\subsection{Digitalizálás és szúrés}

A munkafolyamat során az eddig elkészült adatok szúrése és tisztítása mellett az épületek poligonjainak létrehozására is szükség volt, mely az ArcGIS Pro szoftver segítségével történt meg. A pontfelhőbôl a LAStools eszköztár eszközeinek segítségével a vegetáció kivágásra került az előzóekben létrehozott maszk alapján. További automatikus osztályzás és a nem szükséges pontok (kémények, tetôk alatti részek stb.) eliminálása után az épületpoligonok alapján a tetôkön kívüli részeket is kivágtuk.

\subsection{Síkdetektálás és modellalkotás}

A feldolgozás egyik meghatározó lépése a 3D pontfelhôbôl az egyes tetôsíkok kinyerése volt, ehhez a CloudCompare nyílt forráskódú, pontfelhôk megjelenítésére és feldolgozására alkalmas szoftver, ezen belül pedig a különbözó síkok detektálására alkalmas RANSAC-algoritmus, illetve a hozzá kapcsolódó, parancssorból futtatható „Ransac shape detection" nevú plugin (Schnabel et al. 2007) volt segítségünkre (Varga 2020).

A RANSAC (Fischler-Bolles 1981) egy iteratív módszer, mely egy matematikai modell paramétereinek becslését végzi olyan adathalmazból, mely nagyszámú, kilógó, oda nem illố pontot (outlier) tartalmaz. Múködésének alapelve, hogy az algoritmus véletlenszerú módon (RANdom) egy részhalmazt (SAmple) választ ki az adathalmazból, majd arra illeszt egy modellt. Ezután az algoritmus a többi pontra meghatározza, hogy azok mennyire illeszkednek az elôzóleg kapott, becsült modellhez, amelynek feltétele, hogy a megadott küszöbértéknek (hibahatárnak) megfeleljenek (Barath-Matas 2018, Derpanis 2010). Az iteráció során a legtöbb illeszkedô ponttal (inlier) rendelkezố modellt finomítja azok alapján (pl. legkisebb négyzetes illesztés), a halmaz pontjait az adott modellhez tartozónak

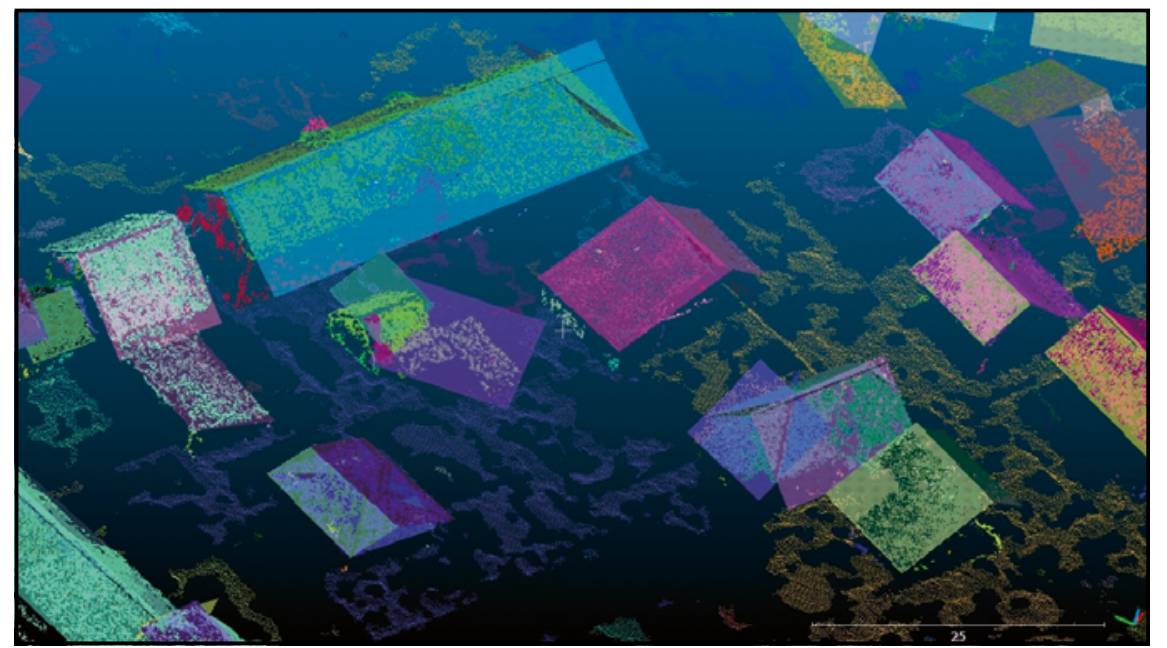

3. ábra. A RANSAC síkdetektálás eredményének részlete

feltételezi (Consensus) és tárolja a finomított verzió paramétereit. Az iterációk száma a feldolgozás idejére és az eredmények pontosságára is egyaránt erốs befolyással van.

Az algoritmus futtatása elótt a szoftverben megtalálható eszközökkel a földi pontok elkülönítésre kerültek (CSF filter), illetve egy zajszúrố (noise filter) algoritmust is lefuttattunk a lehetô legjobb eredmény érdekében. Az így kapott adat már alkalmas volt a RANSAC síkdetektáló és illesztô algoritmus alkalmazásával az egyes tetôsíkok kinyerésére. Az eredményeket exportáltuk, majd ESRI (3D) Shape-formátumba konvertáltuk (3. ábra). Ahol a kapott objektumok nem illeszkedtek megfelelôen, vagy átfedésben voltak, ott manuális módon a javításuk, egymáshoz illesztésük is megtörtént. Az digitalizált épületpoligonok és a tetősíkok 3D-ben történô kiterjesztése, majd az egymást térben átfedô részek kinyerése után létrejöttek a detektált síkokhoz és a digitalizált poligonokhoz egyaránt illeszkedô 3D-s épületmodellek.

\subsection{Napenergia- \\ potenciál számítása}

Az ArcGIS Pro „Area Solar Radiation” eszközét alkalmaztuk a globális besugárzás értékeinek meghatározására, adott idôpontokban, mely figyelembe veszi a felszínmodell magassági értékeit - ami a különféle kitakarások, árnyékok (pl. vegetáció, épületek stb.) szempontjából rendkívül hasznos -, továbbá a kitettségi és lejtôszögértékeket is. A számítás során számos, a Napra, a légkörre és az idôpontra vonatkozó változó definiálása szükséges, melyek aztán az eredményre és a feldolgozás hosszára is jelentôs hatással vannak. Mindkét mintaterületen a 2019-es év minden napján, óránkénti intervallumban történt meg a beesố sugárzás értékének kiszámítása (4. ábra). Az eszköz egyetlen bemeneti állománya az elôzőekben létrehozott felszínmodell volt, a kalkulációhoz szükséges minden információt (magasság, lejtôszög és kitettség) ebbôl, illetve az adott pontok földrajzi helyzetéból

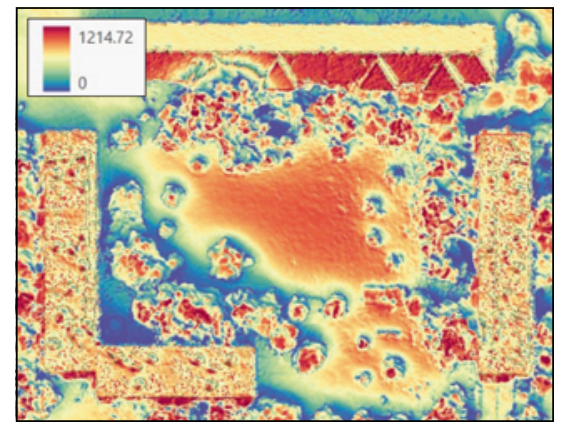

4. ábra. A teljes globális besugárzási raszter részlete ( $\left.\mathrm{kWh} / \mathrm{m}^{2} / e ́ v\right)$

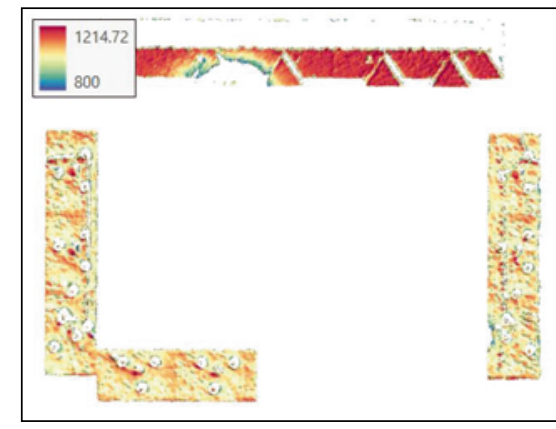

5. ábra. A tisztított globális besugárzási raszter részlete ( $\left.\mathrm{kWh} / \mathrm{m}^{2} / e ́ v\right)$ 
(napsugarak beesési szöge, sugárzási idô, tulajdonképpen a Nap égbolti helyzete) nyertük ki a futtatás során.

Különbözô feltételek megfogalmazásával a $800 \mathrm{kWh} / \mathrm{m}^{2} /$ év-nél kisebb globális besugárzási értékkel rendelkezô, az északi kitettségú és a 45 foknál meredekebb lejtôszögú területek kivágásra kerültek (5. ábra). Az egyes épületpoligonok területére esô pixelértékek statisztikai értékeit is kiszámítottuk, illetve hozzárendeltük (min., max., átlag, összeg). A kis területú tetôszegmenseket kizártuk a további számításokból, így a megmaradt tetôfelületek elméletben megfelelőek a panelek telepítésére.

Az adattáblába két új mező is került, egy az adott szegmens területére esô teljes besugárzási értéket, egy pedig az ebből származtatott ténylegesen felhasználható energia-potenciál értékét tartalmazza. Előbbit az adott szegmens átlagos besugárzási értékének $\mathrm{MWh} / \mathrm{m}^{2} /$ év-be történô átváltása és a szegmens területével való szorzása után kapjuk meg. A tényleges kapacitás számításánál figyelembe kell venni a napelemek hatásfokát is, azaz azt, hogy a napelemet ért napsugárzás hány százalékát tudja hasznosítani az adott panel. Ez az érték átlagosan 15\% körül mozog. A másik fontos tényezô a rendszer múködése során fellépó veszteség, mely alapvetően a rendszer felépítéséből adódik. Ez az érték is $15 \%$ körülire tehetô (United States Environmental Protection Agency 2020). Így tehát, ha a tetôre érkezô összsugárzást megszorozzuk 0,15-tel, megkapjuk a hatékonyan feldolgozott energiamennyiséget, melynek a 85\%át véve megkapjuk a végsô, veszteség utáni értékeinket, azaz azt, hogy egy tetôszegmens potenciálisan mennyi energiát tud termelni (MWh-ban) az adott évben. Nyilvánvaló, hogy a valóságban ez kevesebb valamennyivel, hiszen a számítás során a sík teljes területére kapunk értéket, de nem mindig lehet a teljes tetôsíkot napelemekkel lefedni, többek között a tetôkön található különféle objektumok, ablakok, kémények, szellőzők jelenléte miatt. Ezek elkülönítése a homogén tetőfelületektôl további, jövőbeli munka célját képezi majd.

\subsection{A modellek vizualizációja} Az eredményül kapott 3D-s modellek bemutatása az ESRI CityEngine, procedurális modellezési eljárásokon alapuló szoftverének használatával történt (6. és 7. ábra). A módszer alkalmazása során a számítógép egy, a felhasználó által megfogalmazott, több parancsból álló kódalapú „eljárást”, végrehajtási módot kap. A felhasználó nem közvetlen módon szerkeszti a modellt, hanem az elvégzendô feladatot attól elvonatkoztatva, szabályokkal, egy rule-fájlban fogalmazza meg. A program a szabályokat a CGA (Computer Generated Architecture) shape grammar, azaz egy alakzatokra vonatkozó programozási nyelv alkalmazásával értelmezi és hajtja végre, melyet 3D-s építészeti objektumok létrehozására terveztek.

\section{Eredmények}

A számításokból kiderült, hogy az alsóvárosi területen található tetôszegmensek átlagos szolárenergiapotenciálja 8,23 MWh/év, míg a vértói mintaterületen ez az érték 33,34 MWh/év volt. Az 1. táblázatban látható eredmények jól mutatják a két mintaterület jellege közötti különbséget. Alsóvároson sokkal inkább a családi, társas- és sorházak dominálnak, kisebb és alacsonyabban található tetôfelületekkel, melyeken a vegetáció hatása is sokkal jobban érvényesül. A vértói mintaterületen alapvetốn panelek, nagyobb méretú társasházak és üzletek (kiugróan nagy területe miatt zárójelben a Tesco áruház értékei nélkül mért eredmények) a jellemzőek, nagy területú, lapos, takarásmentes tetőfelületekkel.

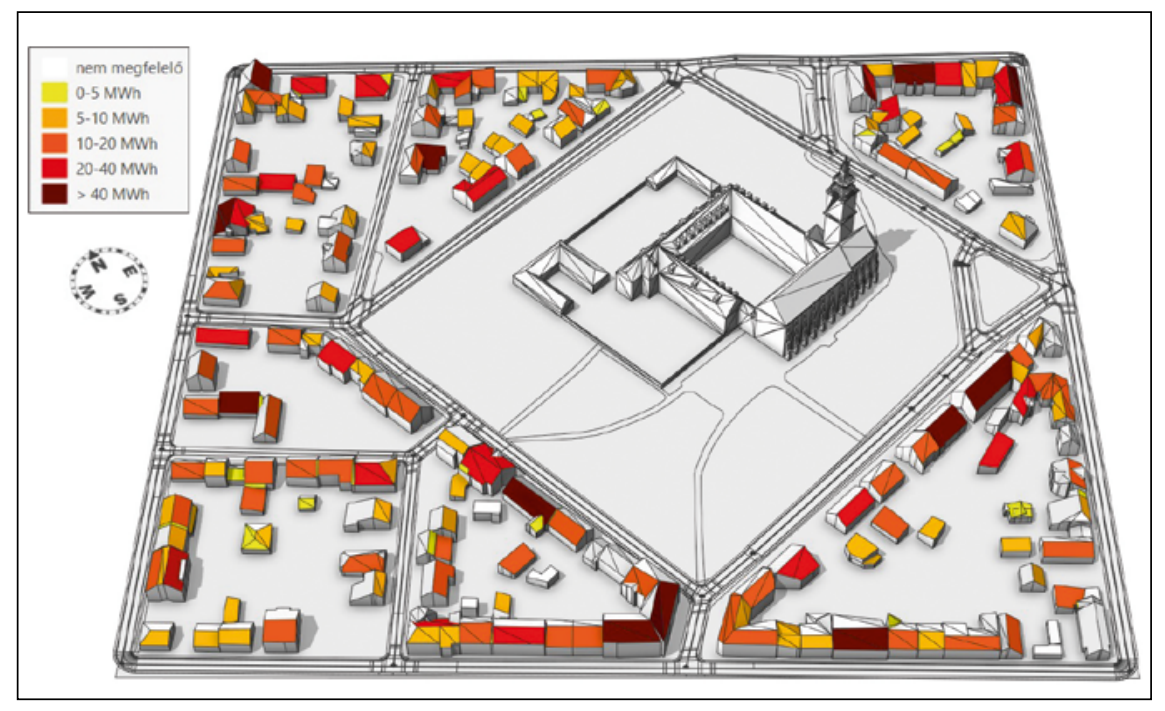

6. ábra. Az egyes tetốsíkok éves napenergia-potenciálja, Alsóváros mintaterület

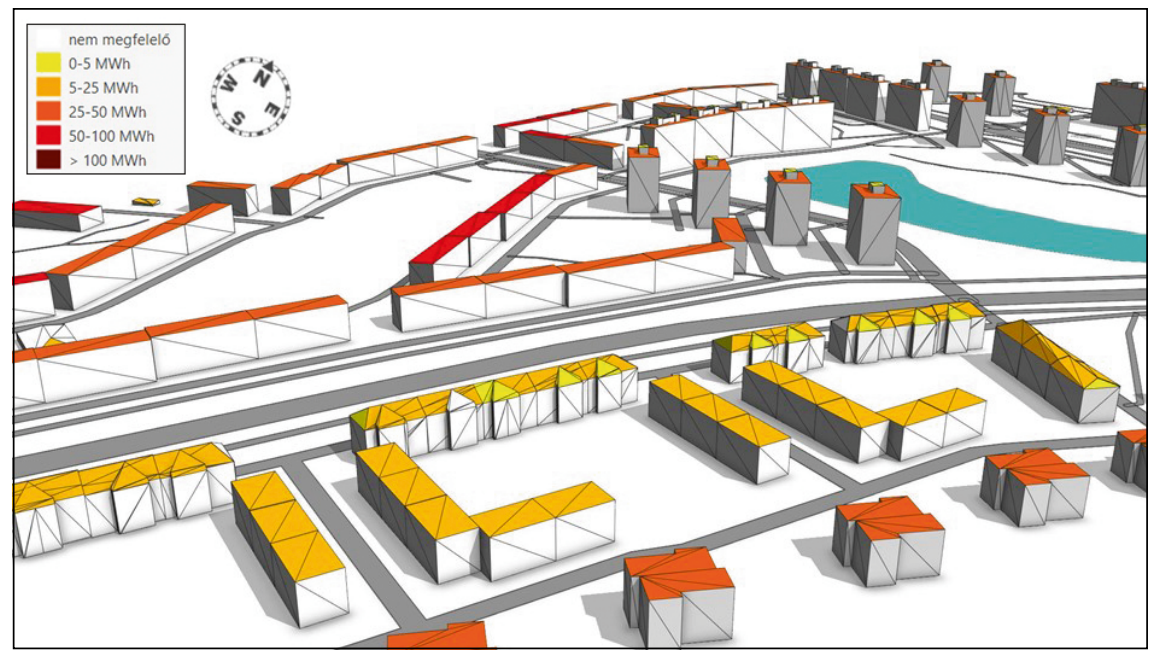

7. ábra. Az egyes tetôsíkok éves napenergia-potenciálja, Vértó mintaterület részlete 
1. táblázat.

A mintaterületek épületeire vonatkozó eredmények

\begin{tabular}{|r|r|r|}
\hline & Vértó mintaterület & Alsóváros mintaterület \\
\hline összes épület (db) & 159 & 232 \\
\hline összes szegmens (db) & 395 & 380 \\
\hline alkalmas szegmens (db) & 322 & 248 \\
\hline átlag (MWh/év) & $33,34(26,17)$ & 8,23 \\
\hline terület összpotenciál (MWh/év) & $10736,63(8402,31)$ & 2041,04 \\
\hline
\end{tabular}

2. táblázat.

Az elméleti fedettségi értékeknek megfelelố szegmensek

2,16 MWh/év teljesítményt elérố szegmensek (db)

\begin{tabular}{|r|r|r|}
\hline elméleti fedettség (\%) & Vértó mintaterület & Alsóváros mintaterület \\
\hline $\mathbf{1 0 0}$ & $310(96,27 \%)$ & $183(93,79 \%)$ \\
\hline $\mathbf{7 5}$ & $288(89,44 \%)$ & $177(71,37 \%)$ \\
\hline $\mathbf{5 0}$ & $237(73,62 \%)$ & $169(68,14 \%)$ \\
\hline 25 & $177(54,97 \%)$ & $112(45,16 \%)$ \\
\hline
\end{tabular}

3. táblázat.

A mintaterületekre esố potenciálértékek

\begin{tabular}{|r|r|r|r|}
\hline & \multicolumn{1}{|c|}{$\begin{array}{c}\text { Vértó } \\
\text { mintaterület }\end{array}$} & $\begin{array}{c}\text { Alsóváros } \\
\text { mintaterület }\end{array}$ & Mértékegység \\
\hline az összes alkalmas terület & 86609,35 & 15744,23 & $\mathrm{~m}^{2}$ \\
\hline $\begin{array}{r}\text { az alkalmas területekre } \\
\text { jutó összes energia }\end{array}$ & $\mathbf{8 4 2 0 8 , 8 5 1 6}$ & 15513,6782 & $\mathrm{MWh} / \mathrm{e} v$ \\
\hline $\mathbf{1} \mathbf{~ m}^{2}$-re jutó évi energia & 0,97228 & 0,98536 & $\mathrm{MWh} / \mathrm{év}$ \\
\hline $\mathbf{1} \mathbf{~ m}^{2}$-re jutó napi energia & 0,00266 & 0,00270 & $\mathrm{MWh} / \mathrm{nap}$ \\
\hline $\mathbf{1} \mathbf{~ m}^{2}$-re jutó napi energia & 9,58965 & 9,71859 & $\mathrm{MJ} / \mathrm{nap}$ \\
\hline
\end{tabular}

A 2. táblázat értékei megmutatják, hogy egy elméleti, napelemekkel történő befedés esetén hány szegmens éri el az egy háztartási fogyasztóra jutó évi villamosenergia-fogyasztást, mely Magyarországon 2018-ban 2,16 MWh volt (Központi Statisztikai Hivatal 2019). A 3. táblázatban a kapott eredmények 1 négyzetméterre vonatkoztatott értékei találhatóak. Fontos megemlíteni, hogy a vizsgálat egy erôsen idealizált helyzetet feltételez, a panelek teljesítménye rendkívül sok tényezôtôl függ. Ilyen például elsôsorban a földrajzi helyzet, az idôjárás és a légkör jellemzói, a panelek típusa, minôsége stb. Amennyiben az lehetséges, a tényleges rendszerek tervezése és kivitelezése során számolnunk kell ezekkel a változókkal a megfelelô eredmény érdekében.

\section{4. Összefoglalás}

A vizsgálat során a fố cél a fotogrammetriai módszerekkel feldolgozott légi felvételekbôl kinyert adatok felhasználása volt 3D-s épületmodellek létrehozása, illetve az azokon alapuló szolárenergia-potenciál számításának elvégzése érdekében. A különbözô lépések során számos módszert alkalmaztunk. Az objektumalapú képelemzés - amellyel a vegetációt különítettük el - megfelelố eredményt szolgáltatott, ám ehhez az egyes beállítások és küszöbértékek gondos megválasztása elengedhetetlen volt. A RANSACalgoritmuson alapuló síkdetektálás is alkalmasnak bizonyult a kívánt eredmények tekintetében, azonban a módszer korlátaira is fény derült: az algoritmus számára nem ismert, hogy a pontfelhô, amiben a síkokat detektálja, mit „ábrázol”, azaz pl. az egymáshoz kapcsolódó, lapos tetôkkel rendelkezô épületeket egy síkként kezelte. További problémát jelentett, hogy az eredményül kapott tetôsíkok sok esetben nem illeszkedtek egymáshoz megfelelôen, vagy túllógtak a tető valós kiterjedésén. Ennek oka, hogy az algoritmus komplex alakzatok detektálására nem alkalmas, így a hibák javítása manuális módon történt meg, ezzel jelentôsen megnövelve a folyamat idő- és munkaigényét. A jövőben ezt a lépést célszerú továbbfejleszteni, vagy egyéb alakzatfelismerô és -illesztô eljárásokkal bôvíteni. A számítások során felhasznált geometriákon található egyedibb, összetettebb objektumokat (ablakok, kémények, antennák stb.) nem vettük figyelembe. Ezek detektálása és modellezése a továbbiakban a feldolgozás hasznos lépése lehet. Az alkalmazott módszerek összességében tehát alkalmasak az ilyen jellegú vizsgálatok elvégzésére, a fentebb említett korlátok és esetleges fejlesztések, finomítások figyelembevételével.

A kapott eredmények alapján elmondható, hogy a mintaterületek épületeinek döntô része alkalmas napelemek telepítésére, és a bennük rejlő potenciál mindenképpen említésre méltó mindkét vizsgált területen. Fontos megjegyezni, hogy számos változó befolyásolhatja az eredményeket, megválasztásuk mindig az adott vizsgálat körülményeitől függ. A számítások során ideális, napos idôt, tiszta égboltot feltételeztünk, melynél a valóság nyilvánvalóan árnyaltabb. Ahogyan azt Gál és Unger (2011) kutatása is jól mutatja, az épületek árnyékoló, kitakaró hatása számottevốen befolyásolja a tetôk potenciális szolárisenergia-bevételét, az évszakok és az idôjárás változásainak függvényében. Munkájuk során az év négy kitüntetett napján (nap-éj egyenlőségek, napfordulók) vizsgálták Szeged belvárosában található tetôk energiapotenciálját. Míg nyáron, júniusban az értékek $25 \mathrm{MJ} / \mathrm{m}^{2}$ körül mozogtak, ugyanezen területen decemberben már csak $5 \mathrm{MJ} / \mathrm{m}^{2}$ körüli értékeket kaptak, átlagosan $14,84 \mathrm{MJ} / \mathrm{m}^{2} /$ nap volt a potenciál. Az általunk kapott értékek egy napra átlagosan az Alsóváros mintaterületen $9,72 \mathrm{MJ} / \mathrm{m}^{2}$, a Vértó mintaterületen pedig $9,59 \mathrm{MJ} / \mathrm{m}^{2}$ voltak. A nagyságrendileg egyezô eredmények megerôsítést adnak a számítások helyességérôl, a különbségek pedig alátámasztják a befolyásoló tényezôk (pl. idôjárás, időbeli felbontás) és körülmények (pl. a terület adottságai, épületmagasságok) fontosságát a hasonló vizsgálatok során. Az Alsóváros mintaterületen az épületek magasságának változatossága és a vegetáció jelenléte erôsen befolyásolja a potenciált. A vértói mintaterületen az épületek nem takarták ki egymást, a növényzet jelenléte sem jellemző. Az alacsonyabb értékeket magyarázhatja, hogy a belvárossal ellentétben itt szinte csak lapos tetôk találhatóak, ennek megfelelốen a 
számítások során használt lejtőszög- és kitettségi értékek is ezeken alapultak. A napelemeket viszont az ilyen felületekre is döntve, az adott viszonyoknak megfelelően szokás telepíteni.

Az elméleti eredmények mellett érdemes figyelembe venni az aktuálisan adott jogi, illetve infrastrukturális körülményeket, melyek gyakran inkább korlátozói, mint elốsegítôi a napelemes rendszerek telepítésnek. Szegeden, annak kedvezố fekvésének köszönhetóen a geotermikus energia mellett számottevố lehetôség rejlik a Napból származó sugárzás megújuló, zöld energiaforrásként való hasznosításában is, melynek jelenlegi, alacsony részesedése a többi energiaforráshoz képest a jövőben orvosolandó feladatunk lesz.

\section{Köszönetnyilvánítás}

A kutatás az Innovációs és Technológiai Minisztérium TKP2020 Tématerületi Kiválósági Program (NKFIH-1279-2/2020. azonosító szám) és a NKFI-6 K124648 sz. projekt támogatásával valósult meg.

\section{Irodalomjegyzék}

Barath, D. - Matas, J. 2018. Graph-cut ransac. In Proceedings of the IEEE Conference on Computer Vision and Pattern Recognition, pp. 6733-6741.

DOI: $10.1109 /$ CVPR.2018.00704

Blaschke, T. 2010. Object based image analysis for remote sensing. In ISPRS journal of photogrammetry and remote sensing, 65(1), pp. 2-16.

DOI: $10.1016 /$ i.isprsiprs.2009.06.004

Derpanis, K. G. 2010. Overview of the RANSAC Algorithm. In Image Rochester $N Y$, 4(1), pp. 2-3.

Fischler, M. A. - Bolles, R. C. 1981. Random sample consensus: a paradigm for model fitting with applications to image analysis and automated cartography. In Communications of the ACM, 24(6), pp. 381-395. DOI: $10.1145 / 358669.358692$

Frank, M. - Mucsi, L. 2014. Automatikus felületmodell-előállítás és szoláris energia-bevétel számítása egy szegedi mintaterületen. Geodézia és Kartográfia, 2014/1-2 (66. évf.) pp. 16-22.

Gál, T. - Unger, J. 2011. Tetôk potenciális szoláris energia-bevételének kiszámítása egy belvárosi területen. In Magyar Épületgépészet, 60(10), pp. 7-10.

Gál, T. - Mucsi, L. 2015. Naperốmú termelésbecslése rövidtávú idôjárás elốrejelzô modell segítségével. In Tovább egy zöldebb úton: A Szegedi Tudományegyetem Földrajzi és Földtani Tanszékcsoport részvétele a ZENFE programban (2013-2015). pp. 27-31.
Hay, G. J. - Castilla, G. 2008. Geographic Object-Based Image Analysis (GEOBIA): A new name for a new discipline. In Blaschke, T., Lang, S., Hay, G. (Eds.): Object Based Image Analysis. Springer, Heidelberg, Berlin, New York, pp. 75-89. DOI: $10.1007 / 978-3-540-77058-9$

Hammer, A. - Heinemann, D. - Hoyer, C. Kuhlemann, R. - Lorenz, E. - Müller, R. Beyer, H. G. 2003. Solar energy assessment using remote sensing technologies. Remote Sensing of Environment, 86(3), pp. 423-432. DOI: $10.1016 / \mathrm{S} 0034-4257(03) 00083-\mathrm{X}$

Henits, L. - Mucsi, L. - Liska, Cs. M. 2017. Monitoring the changes in impervious surface ratio and urban heat island intensity between 1987 and 2011 in Szeged, Hungary. Environmental Monitoring And Assessment, 189(2) Paper(86), p. 13 DOI: $10.1007 / \mathrm{s} 10661-017-5779-8$

Hofierka, J. - Šúri, M. 2002. The solar radiation model for Open source GIS: implementation and applications. In Proceedings of the Open source GIS-GRASS users conference, Vol. 2002, pp. 51-70.

Hossain, M. D. - Chen, D. 2019. Segmentation for object-based image analysis (obia): A review of algorithms and challenges from remote sensing perspective. ISPRS Journal of Photogrammetry and Remote Sensing, 150, pp. 115-134.

DOI: $10.1016 /$ j.isprsjprs.2019.02.009

Kodysh, J. B. - Omitaomu, O. A. - Bhaduri, B. L. - Neish, B. S. 2013. Methodology for estimating solar potential on multiple building rooftops for photovoltaic systems. Sustainable Cities and Society, 8, pp. 31-41. DOI: 10.1016/j.scs.2013.01.002

Mohandes, M. - Rehman, S. - Halawani, T. O 1998. Estimation of global solar radiation using artificial neural networks. Renewable energy, 14(1-4), pp. 179-184. DOI: $10.1016 / \mathrm{s} 0960-1481(98) 00065-2$

Mubiru, J. - Banda, E. J. K. B. 2008. Estimation of monthly average daily global solar irradiation using artificial neural networks. Solar Energy, 82(2), pp. 181-187. DOI: 10.1016/i.solener.2007.06.003

Schnabel, R. - Wahl, R. - Klein, R. 2007. Efficient RANSAC for point-cloud shape detection. In Computer graphics forum (Vol. 26, No. 2) Oxford, UK: Blackwell Publishing Ltd, pp. 214-226. DOI: $10.1111 /$ j.1467-8659.2007.01016.x

Szatmári, J. - Tobak, Z. - Varga, Á. 2019. Okos város - 3D GIS fejlesztés Szeged városi mintaterületekre. Térinformatikai Konferencia és Szakkiállítás, Debrecen, 2019. máj. 23-24. pp. 412-413.

Szabó, Sz. - Enyedi, P. - Horváth, M. - Kovács, Z. - Burai, P. - Csoknyai, T. - Szabó, G 2016. Automated registration of potential locations for solar energy production with Light Detection And Ranging (LiDAR) and small format photogrammetry. Journal of Cleaner Production, Volume 112, Part 5, pp. 3820-3829.

DOI: $\underline{10.1016 / \text { i.jclepro.2015.07.117 }}$

Šúri, M. - Hofierka, J. 2004. A new GIS-based solar radiation model and its application to photovoltaic assessments. Transactions in GIS, 8(2), pp. 175-190.

DOI: $10.1111 / \mathrm{j} .1467-9671.2004 .00174 . \mathrm{x}$

Tymvios, F. S. - Jacovides, C. P. - Michaelides S. C. - Scouteli, C. 2005. Comparative study of Ångström's and artificial neural networks' methodologies in estimating global solar radiation. Solar energy, 78(6), pp. 752762. DOI: 10.1016/j.solener.2004.09.007

Varga, Á. 2020. 3D városmodellezés fotogrammetriai módszerekkel elốllított adatok felhasználásával. Diplomadolgozat, Szegedi Tudományegyetem, Geoinformatikai, Természet- és Környezetföldrajzi Tanszék, témavezetô: Szatmári József.

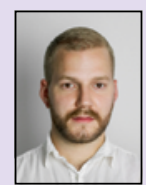

\section{Varga Ákos}

doktorandusz

SZTE Geoinformatikai, Természet- és Környezetföldrajzi Tanszék vga.akos@gmail.com

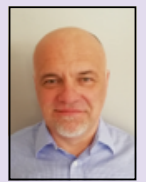

Dr. Szatmári
József
egyetemi
docens

SZTE Geoinformatikai, Természet- és Környezetföldrajzi Tanszék szatmari.jozsef@szte.hu

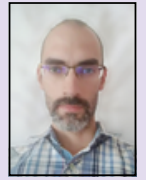

\section{Dr. Tobak Zalán} egyetemi adjunktus

SZTE Geoinformatikai, Természet- és Környezetföldrajzi Tanszék tobak@geo.u-szeged.hu

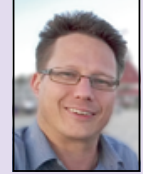

\section{Dr. Boudewijn van Leeuwen egyetemi adjunktus}

SZTE Geoinformatikai, Természet- és Környezetföldrajzi Tanszék leeuwen@geo.u-szeged.hu

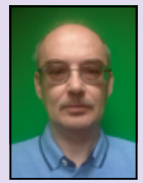

Dr. Mucsi László egyetemi docens

SZTE Geoinformatikai, Természet- és Környezetföldrajzi Tanszék mucsi.laszlo@szte.hu 